\title{
PELAYANAN BAGI ANAK DENGAN KECACATAN DI KOTA CIMAHI
}

\author{
Oleh: \\ Nurliana C. Apsari, S.Sos., MSW. \\ Departemen Kesejahteraan Sosial FISIP Unpad
}

Email:nurliana.apsari@gmail.com

\begin{abstract}
ABSTRAK
Anak dengan kecacatan beresiko mendapatkan perlakuan salah dari masyarakat sebagi akibat dari ketidaksadaran dan ketidaktahuan masyarakat mengenai kondisi anak dengan kecacatan dan ketersediaan layanan bagi mereka. Kondisi ini membuat pihak berwenang harus lebih terlibat dalam beragam layanan untuk memenuhi kebutuhan mereka.

Penelitian ini dilaksanakan untuk mengidentifikasi layanan-layanan yang diberikan baik oleh pemerintah maupun oleh lembaga-lembaga swasta bagi anak-anak dengan kecacatan dan keluarganya. Selain untuk mengidentifikasi, penelitian ini juga bertujuan untuk melihat kemudahan keluarga untuk mengakses layanan-layanan yang telah ada. Metode yang digunakan dalam penelitian adalah kualitatif dan data dikumpulkan dengan menggunakan FGD dan wawancara mendalam dengan para informan terpilih. Penelitian dilakukan di Kota Cimahi Provinsi Jawa Barat, Indonesia.

Penelitian menemukan bahwa data mengenai anak dengan kecacatan dan tipe kecacatan masih terbatas. Untuk layanan pendidikan di Kota Cimahi, ada 8 sekolah luar biasa tersedia bagi anak-anak dengan kecacatan di Kota Cimahi. Sementara itu, untuk layanan kesehatan bagi anak dengan kecacatan, jaminan sosial di bidang kesehatan mudah diakses dan didapatkan oleh keluarga dan informasi mengenai layanan juga tersedia bagi keluarga anak dengan kecacatan. Penelitian juga menemukan tantangan bagi keluarga untuk mengakses layanan adalah pada persyaratan akademis. Dapat disimpulkan bahwa layanan bagi anak dengan kecacatan masih sangat terbatas, dan tidak ada layanan yang dirancang oleh orang tua yang memiliki anak dengan kecacatan.

Penelitian merekomendasikan pihak berwenang dan penyedia layanan untuk memusatkan perhatian pada perencanaan dan pengembangan layanan sehingga mereka dapat turut serta secara aktif memutuskan beragam layanan yang dibutuhkan untuk memenuhi kebutuhan anak-anak dengan kecacatan.
\end{abstract}

Kata kunci: layanan sosial, anak dengan kecacatan

\section{Pendahuluan}

Anak dengan kecacatan termasuk dalam kategori populasi yang rawan mendapatkan perlakuan yang tidak sesuai dengan haknya. Negara Indonesia yang telah meratifikasi Konvensi Hak Anak tentunya memiliki kewajiban sebagai "Duty Bearer" untuk memenuhi hak anak tersebut, terutama hak anak dengan kecacatan. Konvensi hak anak terdiri dari 4 domain utama menurut Protacio-De Castro, et.al. (2005) yaitu Keberlangsungan hidup, Pengembangan diri, Perlindungan dan Partisipasi. 
Bagi anak dengan kecacatan, pemenuhan hak tersebut menjadi sangat penting agar dapat tumbuh dan berkembang menjadi individu yang mandiri. Anak dengan kecacatan dan keluarganya harus mendapatkan kesempatan dan akses kepada layanan yang dapat mendukung kemandirian anak tersebut. Masa anak-anak dan masa remaja bagi yang normal dan berada dalam situasi terbaik dalam kehidupan mereka sendiri saja sudah merupakan masa yang penuh tantangan, apalagi dengan anak dan remaja yang mengalami kecacatan, baik itu karena kecelakaan maupun bawaan semenjak lahir atau genetika.

Penyandang cacat, sesuai dengan UU No. 4 tahun 1997 didefinisikan sebagai setiap orang yang memiliki kelainan fisik dan/atau mental yang dapat mengganggu atau merupakan rintangan dan hambatan baginya untuk melakukan aktifitas secara selayaknya, yang terdiri dari penyandang cacat fisik, penyandang cacat mental dan penyandang cacat fisik dan mental.

Menteri Sosial Republik Indonesia menyatakan sebagaimana dikutip oleh Antaranews.com bahwa terdapat 2,8 juta orang penyandang cacat dari jumlah penduduk Indonesia dan anggaran pemerintah untuk penyandang cacat masih minim (http://www.antaranews.com/berita/399334/p enyandang-cacat-di-indonesia-

mencapai-28-juta, 25 Maret 2014). Sementara itu, untuk data anak penyandang cacat dengan rentang usia 0-21 tahun, menurut Jenis Cacat (dalam ribuan) yang diolah berdasarkan hasil Susenas, 2003 dan 2005 adalah sebagai berikut:
Tabel 1

Jumlah Anak Cacat

\begin{tabular}{lcc}
\hline Jenis Cacat & 2000 & 2003 \\
\hline Tuli & 37,8 & 23,5 \\
Bisu & 49,8 & 73,1 \\
Tuli dan & & \\
Bisu & 11,8 & 42,7 \\
Cacat tubuh & 114,5 & 156,9 \\
Cacat & & \\
mental & 38,4 & 118,1 \\
Gangguan jiwa & 16,6 & 26,7 \\
\multicolumn{2}{l}{ Sumber: YKAI.net dan hasil modifikasi } \\
peneliti
\end{tabular}

Berkaitan dengan minimnya anggaran pemerintah pusat tersebut, membuat pemerintah daerah harus mencari cara sendiri untuk dapat membantu para penyandang cacat sehingga mereka dapat membantu diri mereka sendiri.

Penelitian ini dilakukan untuk melihat pelayanan yang tersedia bagi anak dengan kecacatan di Kota Cimahi, karena Kota Cimahi adalah kota yang area pelayananannya relative lebih kecil, yang terdiri dari 3 Kecamatan sehingga memungkinkan bagi masyarakat warga Kota Cimahi untuk mengetahui dan mengakses pelayanan yang tersedia bagi anak dengan kecacatan di Kota Cimahi tersebut.

\section{Pelayanan bagi anak dengan kecacatan}

Orang tua selalu mengharapkan anaknya dapat terlahir dengan sempurna dan berharap anak menjadi sumber kebahagiaan bagi mereka. Namun tidak semua anak terlahir sempurna atau sepanjang perjalanan hidupnya, anak tersebut selalu berada dalam 
kondisi sempurna. Anak dengan kecacatan mengalami kondisi yang berbeda dengan anak yang normal. Keadaan tersebut tentunya memunculkan konsekuensi kebutuhankebutuhan akan layanan dalam pemenuhan hak-haknya.

Anak dengan kecacatan yang tinggal dengan keluarga di lingkungan masyarakat tentunya memerlukan layanan yang sesuai dengan kebutuhan mereka. Rothman (1994:6) menyebut bahwa "the chronically mentally ill, frail elderly, and physically disabled are in circumstances of profound hardship". Ini menunjukkan individu dengan kecacatan berada dalam kondisi yang sulit, sehingga wajib bagi pemerintah untuk menyediakan layanan bagi mereka baik itu layanan yang dikelola sendiri oleh pemerintah maupun layanan yang dikelola swasta dengan fasilitas pemerintah. Sayangnya, layanan yang ada maupun yang sedang dalam perencanaan seringkali bersifat parsial dan tidak saling berhubungan diantara lembaga pemerintah maupun non pemerintah.

Anderson (2000:484) mengklaim bahwa "disperate definition and eligibility criteria that are used to identify these disabilities have prevented agencies from collaborating or even communicating about the children with whom they work, resulting in a pervasive lack of coordination among service providers". Ungkapan tersebut menunjukkan bahwa layanan-layanan yang tersedia seringkali tidak terkordinasi dengan baik karena tidak adanya kesamaan definisi dan kriteria yang sama dari setiap penyedia layanan. Dukmak (2009) mengklaim bahwa "there is a major and growing need for coordination of services, resources, program sharing, new pattern of interagency collaboration and cooperative services". Ini menunjukkan bahwa pentingnya koordinasi antara lembaga penyedia layanan bagi anak dengan kecacatan dan keluarga dipengaruhi oleh adanya kolaborasi dan komunikasi yang terbuka diantara penyedia layanan, sehingga layanan bisa tepat sasaran, berkesinambungan dan berkelanjutan.

Keterlibatan orang tua menjadi sangat penting, karena seringkali orang tua tidak mengetahui layanan apa yang sebenarnya tersedia bagi mereka sebagaimana yang dikemukakan oleh Dukmak (2009:1) "parents of children with disability often have difficulty obtaining necessary rehabilitation services from the community". Ini menunjukkan bahwa orang tua sebagai orang terdekat anak dengan kecacatan memainkan peran penting untuk didengar dan diajak serta dalam merancang pelayanan yang diperlukan oleh anak dengan kecacatan. Lebih lanjut, Anderson (2000) dalam penelitiannya menyebutkan bahwa ada beberapa prinsip dalam menyediakan layanan bagi anak dengan kecacatan dan keluarga, yaitu pelibatan orang tua baik sebagai pengidentifikasi layanan yang dibutuhkan dan pendesain rencana pelayanan bagi anakanak dan system dan penyedia layanan harus memiliki kompetensi budaya. Prinsip tersebut didukung pula oleh Freedman \& Fes (1996) dalam Dukmak (2009)

yang menyebutkan bahwa "both the providers of rehabilitation services and policy planners appreciate the value of including parents in the rehabilitation process". Dengan adanya keterlibatan orang tua dalam merancang dan merencanakan pelayanan bagi anak dengan kecacatan akan meminimalisir efek dari ketidaktahuan orang tua mengenai layanan yang ada bagi mereka sehingga tidak ada lagi alasan bagi mereka untuk tidak 
mengetahui dan tidak memiliki akses untuk pemenuhan kebutuhan anak mereka.

\section{Metodologi}

Study ini dilaksanakan dengan menggunakan desain kualitatif untuk mengetahui kondisi di lapangan saat pengumpulan data. Pengumpulan data akan dilakukan dengan metode wawancara individual terhadap pihak-pihak yang bersinggungan dengan pelayanan yang diberikan kepada anak dengan kecacatan dan keluarganya. Observasi dan studi data sekunder dilakukan untuk melengkapi hasil wawancara individual.

Informan diidentifikasi dengan menggunakan teknik purposive, sesuai dengan kebutuhan penelitian. Wawancara individual dilakukan kepada beberapa informan untuk mendapatkan data lebih lengkap mengenai database, layanan, dan aksesibilitas terhadap layanan bagi anak dengan kecacatan dan keluarganya. Wawancara individual dilakukan kepada Unit Pelaksana Teknis Daerah (UPTD) Pendidikan, UPTD Kesehatan. Triangulasi isi dilakukan dengan cara mewawancarai Kepala Sekolah SLB dan Guru-guru SLB di Kota Cimahi mengenai layanan yang tersedia dan aksesibilitas mereka terhadap layanan tersebut. Studi ini meneliti ketersediaan database anak dengan disabilitas di Kota Cimahi, pemahaman para informan mengenai disabilitas, pengetahuan para informan tentang pelayanan yang tersedia bagi anak dengan kecacatan dan keluarganya serta pengetahuan para informan mengenai cara anak dan keluarga dengan kecacatan mengakses pelayanan yang tersedia.

\section{Hasil dan pembahasan}

Kota Cimahi terletak diantara 107³0’30" BT - 107'34’30” dan 650’00”- 656’00” Lintang Selatan. Luas wilayah Kota Cimahi yang sebesar 40,2 $\mathrm{Km}^{2}$ menurut UU No. 9 Tahun 2001 dengan batas-batas administratif sebagai berikut:

Sebelah Utara: Kecamatan Parongpong, Kecamatan Cisarua dan Kecamatan Ngamprah Kabupaten Bandung Barat.

Sebelah Timur: Kecamatan Sukasari, Kecamatan Sukajadi, Kecamatan Cicendo dan Kec. Andir Kota Bandung

Sebelah Selatan: Kecamatan Marga Asih, Kecamatan Batujajar, Kabupaten Bandung Barat dan Bandung Kulon Kota.

Sebelah Barat Kecamatan

Padalarang, Kecamatan Batujajar dan Kecamatan

Ngamprah Kabupaten Bandung Barat.

Kota Cimahi termasuk ke dalam wilayah Propinsi Jawa Barat dan meliputi 3 Kecamatan yang terdiri dari 15 Kelurahan, yaitu : Kecamatan Cimahi Utara terdiri dari 4 Kelurahan, Kecamatan Cimahi Tengah terdiri dari 6 Kelurahan dan Kecamatan Cimahi Selatan terdiri dari 5 Kelurahan. Secara geografis wilayah ini merupakan lembah cekungan yang melandai ke arah selatan, dengan ketinggian di bagian utara $\pm 1,040$ meter dpl ( Kelurahan Cipageran Kecamatan Cimahi Utara), yang merupakan lereng Gunung Burangrang dan Gunung Tangkuban Perahu serta ketinggian di bagian selatan sekitar \pm 685 meter dpl (Kelurahan Melong Kecamatan Cimahi 
Selatan) yang mengarah ke Sungai Citarum. Sungai yang melalui Kota Cimahi adalah Sungai Cimahi dengan debit air rata-rata $3.830 \mathrm{l} / \mathrm{dt}$, dengan anak sungainya ada lima yaitu Kali Cibodas, Ciputri, Cimindi, Cibeureum (masingmasing di bawah 200 1/dt) dan Kali Cisangkan (496 1/dt), sementara itu mata air yang terdapat di Kota Cimahi adalah mata air Cikuda dengan debit air 4 1/dt dan mata air Cisintok (931/dt).

Dengan luas wilayah tersebut, jumlah penduduk Kota Cimahi mencapai angka 600 ribu jiwa, yang tersebar di 3 kecamatan di Kota Cimahi. Berikut adalah tabel jumlah penduduk Kota Cimahi berdasarkan jenis kelamin. Sementara itu, berdasarkan kelompok umur, Kota Cimahi memiliki potensi sumber daya manusia produktif yang menjanjikan, dengan jumlah tertinggi penduduk berdasarkan kelompok umur jatuh kepada kelompok umur 30-34 tahun. Hal ini menunjukkan bahwa Kota Cimahi mempunyai potensi tenaga kerja yang dapat menyumbangkan pendapatan daerah. Tabel berikut ini akan menggambarkan pembagian penduduk Kota Cimahi berdasarkan kelompok umur.

\section{Tabel 3.2. Penduduk Kota Cimahi Berdasarkan Kelompok Umur}

Sumber: Database Kependudukan Kota

\begin{tabular}{|l|l|l|l|l|l|}
\hline No. & $\begin{array}{l}\text { Klpk } \\
\text { Umur }\end{array}$ & $\mathbf{L}$ & $\mathbf{P}$ & $\begin{array}{l}\text { Jumla } \\
\text { h }\end{array}$ & \% \\
\hline 1 & $75+$ & 2940 & 4543 & 7,483 & 1.22 \\
\hline 2 & $70-74$ & 3375 & 3435 & 6,810 & 1.11 \\
\hline 3 & $65-69$ & 5052 & 5484 & 10,536 & 1.72 \\
\hline 4 & $60-64$ & 6428 & 6604 & 13,032 & 2.13 \\
\hline 5 & $55-59$ & 10831 & 10071 & 20,902 & 3.41 \\
\hline 6 & $50-54$ & 14929 & 13633 & 28,562 & 4.67 \\
\hline 7 & $45-49$ & 18612 & 18351 & 36,963 & 6.04 \\
\hline 8 & $40-44$ & 24484 & 22905 & 47,389 & 7.74 \\
\hline 9 & $35-39$ & 29846 & 28903 & 58,749 & 9.60 \\
\hline 10 & $30-34$ & 33785 & 33498 & 67,283 & 10.99 \\
\hline 11 & $25-29$ & 30756 & 32434 & 63,190 & 10.32 \\
\hline 12 & $20-24$ & 25280 & 24711 & 49,991 & 8.17 \\
\hline 13 & $15-19$ & 24784 & 23971 & 48,755 & 7.96 \\
\hline 14 & $10-14$ & 27962 & 26492 & 54,454 & 8.90 \\
\hline 15 & $5-9$ & 29997 & 28362 & 58,359 & 9.53 \\
\hline 16 & $0-4$ & 20491 & 19219 & 39,710 & 6.49 \\
\hline
\end{tabular}

Cimahi. 2012.

Berdasarkan penelitian, belum ada kategori anak dengan kecacatan atau orang dengan kecacatan dalam sensus penduduk yang dilakukan di Kota Cimahi ini. Penelitian ini diawali dengan melihat database mengenai anak dengan kecacatan baik di Indonesia maupun di Cimahi, kemudian melihat pelayanan yang tersedia bagi anak dengan kecacatan baik itu di bidang pendidikan dan kesehatan. Penelitian dilakukan di bidang pendidikan dan kesehatan karena berdasar pada asumsi bahwa pelayanan yang dapat dirasakan langsung oleh anak dengan kecacatan dan keluarganya adalah layanan di bidang pendidikan dan di bidang kesehatan.

Hasil penelitian menemukan bahwa di Cimahi Utara sejauh ini, pihak kecamatan baru melakukan assessment dan pendataan terhadap anak dengan kecacatan sehingga mereka belum memiliki database mengenai 
kecacatan tersebut, sedangkan di Cimahi Selatan di setiap kelurahan ada data penyandang cacat dan yang bertugas melakukan pendataan tersebut adalah PSM (Pekerja Sosial Masyarakat) di setiap kelurahan. Kegiatan pendataan dilakukan sesuai dengan kebutuhan data, misalnya ketika Dinas membutuhkan data mengenai anak dengan kecacatan atau orang dengan kecacatan untuk digunakan sebagai acuan ketika ada program atau bantuan. Dengan adanya database kecacatan, maka dapat terlihat jenis dan berapa orang dengan kecacatan atau anak dengan kecacatan sehingga dari data tersebut memudahkan ketika ada bantuan atau program dan bantuan yang diberikan dapat disesuaikan dengan jenis kecacatan yang ada. Kegiatan pemutakhiran data individu dengan kecacatan dilakukan setiap 1 tahun sekali. Di Cimahi Tengah, database individu dengan kecacatan dulunya merupakan data PMKS (Penyandang Masalah Kesejahteraan Sosial). Data tersebut kegunaannya adalah untuk pelatihan. Data individu dengan kecacatan seharusnya ada di setiap kecamatan yang digunakan untuk keperluan pemberian bantuan. Data tersebut dikumpulkan melalui RT-RWKec-Dinas.

Gambaran hasil tersebut berarti menunjukkan bahwa bahkan untuk kepentingan database, tidak ada keseragaman cara dan alat yang digunakan untuk melakukan pedataan terhadap individu dengan kecacatan, termasuk anak dengan kecacatan.

Keberadaan database akan sangat mempengaruhi ketersediaan layanan bagi individu yang memerlukan, sehingga layanan akan menjadi lebih efektif dan efisien.
Sementara itu, untuk hasil penelitian mengenai layanan yang tersedia bagi anak dengan kecacatan untuk di Cimahi Utara mayoritas adalah pelayanan yang disediakan oleh pemerintah. Peran pemerintah kecamatan dalam menangani isu disabilitas selama ini, pemerintah telah memberikan berbagai macam pelatihan terkait dengan keberadaan anak dengan kecacatan di lingkungan kecamatan, yaitu:

a. Pelatihan bagi anggota RBM serta bantuan alat dari Dinas Sosial khususnya kursi roda yang dapat dipinjam oleh anak dengan kecacatan

b. Pelatihan yang diberikan kepada orang tua anak dengan kecacatan, tetapi pelatihan yang diberikan tersebut belum memadai karena banyaknya jenis kecacatan

c. Pelatihan terapi bagi orang tua anak dengan kecacatan sehingga dapat mengadakan terapi sendiri bagi anaknya

d. Pelatihan yang diberikan belum sesuai dengan kecacatan yang disandangnya.

Sementara itu di Kecamatan Cimahi Tengah layanan yang tersedia bagi anak dengan kecacatan dibagi menjadi beberapa sektor yaitu ada peran pemerintah kecamatan dalam menangani isu disabilitas yang masih fokus di bidang pendidikan, kesehatan dan ekonomi. Pemerintah juga melakukan sosialisasi melalui kader. Selain itu, Dinas Sosial juga memberikan bantuan dalam bentuk alat bantu seperti kaki palsu. Selain pemerintah di Kecamatan Cimahi Tengah ada juga peran Relawan di masyarakat untuk menangani isu disabilitas dan bantuan yang berasal dari masyarakat kepada anak dengan disabilitas lebih sering berupa bantuan pribadi, walau ada juga bantuan yang berasal dari organisasi pelayanan sosial, seperti Yayasan Pambudi 
di Kelurahan Setiamanah dan Yayasan Mizan Amanah yang memberikan bantuan kepada anak dengan disabilitas berbentuk alat bantu sesuai dengan kebutuhannya. Selain itu juga ada peran NGO internasional (Save the Children) yang memfasilitas masyarakat dalam pembentukan forum keluarga anak dengan kecacatan. Sementara itu untuk di Kecamatan Cimahi Selatan, Peran pemerintah kecamatan dalam menangani isu disabilitas adalah dalam memberikan bantuan modal untuk usaha bersama bagi orang dengan kecacatan, datanya diambil dari data disabilitas yang dilakukan oleh PSM. Sementara itu, bantuan yang diberikan dari warga yang mampu ataupun pabrik dan perusahaan hanya berupa bantuan sembako, itupun sifatnya pada saat-saat tertentu seperti ketika hari raya Idul Fitri. Sementara itu, peran PSM di setiap kelurahan bertugas melakukan pendataan di setiap RT/RW mengenai orang dengan disabilitas dan kemudian melaporkannya ke pihak kecamatan lalu ke Pemerintahan Kota.

Kondisi layanan-layanan yang telah diberikan kepada anak dengan kecacatan di Kecamatan Cimahi Selatan adalah adanya informasi awal bagi orang tua anak dengan kecacatan didapatkan dari pelayanan Posyandu. Dari pelayanan Posyandu lah orang tua mengetahui bahwa anaknya mengalami kelainan. Selain itu, keluarga anak dengan kecacatan merasa mudah untuk mendapatkan layanan tersebut terutama dari segi informasi dirasa cepat dan dari segi administratif dirasa mudah ketika berhubungan dengan pihak kelurahan dan kecamatan. Selain itu, aksesibilitas layanan asuransi sosial yang berasal dari pemerintah untuk kesehatan, sudah terakses dan dirasa mudah untuk didapatkan, begitupula dari sisi informasi mudah untuk diakses. Tetapi, dari sisi administratif dirasa masih ada kendala.

Hasil penelitian mengenai layanan tersebut menunjukkan bahwa layanan yang ada masih bersifat bantuan dan seringkali tidak terintegrasi antara layanan dari sector pemerintah maupun non pemerintah. Selain itu, persyaratan administrative cenderung membatasi akses anak dengan kecacatan dan keluarganya untuk mendapatkan layanan yang mereka perlukan. Hal tersebut mengakibatkan semakin terpinggirkannya pemenuhan hak anak dengan kecacatan baik itu dengan disengaja maupun tidak.

\section{Simpulan dan Rekomendasi}

Berdasarkan uraian sebelumnya, dapat ditarik kesimpulan bahwa layanan di Kota Cimahi untuk anak dengan kecacatan dan keluarganya masih sangat terbatas, dan belum ada pelayanan yang dirancang oleh orang tua anak dengan kecacatan sehingga layanan menjadi lebih efektif dan efisien. Keberadaan kelompok rehabilitasi berbasis masyarakat dan forum keluarga anak dengan kecacatan belum dirasa manfaatnya karena masih baru terbentuk. Meski begitu, rehabilitasi berbasis masyarakat dirasa relevan dengan kebutuhan anak dengan kecacatan dan keluarganya karena mereka tinggal di masyarakat dan masyarakat berperan menjadi sumber penyedia layanan bagi anak dengan kecacatan dengan difasilitasi oleh pemerintah.

Rekomendasi yang dihasilkan dari penelitian ini adalah bahwa pemerintah Kota Cimahi sebaiknya memfokuskan rencana dan desain pelayanan dengan bekerja bersama RBM dan Forum keluarga anak dengan kecacatan, sehingga orang tua dapat 
berperan aktif dalam menentukan layanan apa yang diperlukan oleh mereka untuk memenuhi kebutuhan anaknya.

\section{Daftar Pustaka}

Anderson, J.A. 2000. The Need for

Interagency Collaboration for Children with

Emotional and Behavioral

Disabilities and Their

Families. Families in

Society, Sept/Oct, 81, 5, pp. 484.

Dukmak, S. 2009. Rehabilitation

Services in the United Arab

Emirates as Perceived by Parents

of Children with Disability.

Journal of Rehabilitation, Oct-

Dec 2009; 75, 4.
Protacio-De Castro, E., Camacho,A.Z.V., Balanon, F.A.G., Yacat, J.A., Galang, M.T., Ong, M.G. 2005. Handbook for Social Workers on Basic BioPychosocial Help for Children in Need of Special Protection. Filipina: UNICEF.

Rothman, J. 1994. Practice with highly vulnerable clients: Case management and CommunityBased services. New Jersey: Prentice Hall.

Antaranews,

(http://www.antaranews.com/berita/399334/ penyandang-cacat-di-

indonesia-mencapai-28-juta, diakses 25 Maret 2014).

$\begin{array}{lrr}\text { UNDANG-UNDANG } & \text { NEGARA } \\ \text { REPUBLIK } & \text { INDONESIA } \\ \text { NOMOR } 4 & \text { TAHUN } 1997 \\ \text { TENTANG } & \text { PENYANDANG } \\ \text { CACAT } & & \end{array}$

